LITERATURE AND EPIDEMIOLOGY

\title{
Five American authors on wealth, poverty, and inequality
}

\author{
Ichiro Kawachi, Philippa Howden Chapman
}

J Epidemiol Community Health 2004;58:738-742. doi: 10.1136/jech.2004.021741

There is much to be gleaned from novels concerning the links between wealth and power, inequality and corruption, poverty and illness. A student of social epidemiology will profit as much from close reading of these classics as from consulting textbooks on social stratification.

See end of article for authors' affiliations

Correspondence to: Correspondence to: Harvard School of Public Health, 677 Huntington Avenue, Boston, MA 02115, USA;

Ichiro.Kawachi@

channing.harvard.edu

Accepted for publication 21 April 2004 $\mathrm{t}$ is a truism that novelists reflect the concerns of their times. In this article, we highlight the novels of five American authors who lived and wrote during a period of immense social inequalities and upheaval-the late Victorian period in Great Britain, and the Gilded Age in America. The five novelists we have chosen to highlight are: Henry James (1843-1916), William Dean Howells (1837-1920), Frank Norris (1870-1902), Theodore Dreiser (1871-1945), and Edith Wharton (1862-1937). Within a comparatively brief span of two decades ( 1885 to 1905), these authors produced five novels from which it is possible to take in a sweeping view of the massive transformations that were taking place in societies on both sides of the Atlantic through economic development, the concentration of wealth and power, and intense class conflict. These novels span the entire social hierarchy, from the very top (Wharton) to the bottom (Dreiser). The scale of their canvas extends from the intimate (Howells) to the panoramic (Norris). Their dramatic themes range from the position of women in society (Dreiser and Wharton), to the moral responsibility of individuals engaged in life or death economic struggle (Henry James e tutti).

Besides yielding many hours of aesthetic pleasure, there is much to be gleaned from these novels concerning the links between wealth and power, inequality and corruption, poverty and illness. As we have emphasised in our own pedagogy, a student of social epidemiology will profit as much from a close reading of these classics as consulting a half dozen textbooks on social stratification. We hope readers agree.

\section{THE PRINCESS CASAMASSIMA BY HENRY} JAMES (1886)'

What should be done about the injustice and inequalities of the world? In particular, what should be the individual's response to the misery and suffering of the poor? That is the central question posed by Henry James' novel The Princess Casamassima, set in Victorian England in the 1880s. All shades of individual reactions to this dilemma are portrayed in James' novel, ranging from indifference, to denial, resignation, charity, frustration, resentment, and ultimately, violence. The novel's hero, Hyacinth Robinson, literally embodies the class struggle of that period. He is the bastard son of an English lord murdered by his mistress, a French dressmaker who dies in prison for her crime. Hyacinth is adopted as a child, and grows up in the slums of London. The novelist's depictions of poverty in London emerge through telling, incidental details, such as when he describes the daily amusements of the children growing up in Hyacinth's neighbourhood:

\begin{abstract}
"The little Hennings, unwashed and unchidden, spent most of their time either pushing each other into the gutter or in running to the public-house at the corner for a pennyworth of gin." (page 94) [Selling spirits to persons under 16 was outlawed in England only after the Licensing Act of 1872].
\end{abstract}

Most of the hard working people in the neighbourhood, including Hyacinth, seem resigned to accept their limited lot in life. However, everything is changed for the hero one day when he is introduced to the Princess Casamassima. The Princess turns out to be a dilettante crusader in search of a worthy social cause. She "collects" specimens of the working class like Hyacinth so that she might learn more about their degraded conditions. During the course of repeated visits to satisfy the Princess' curiosity, Hyacinth develops a painful awareness of the great gulf that separates the lives of the toiling masses from the privileged and indolent few. The psychological drama of Henry James' novel unfolds through the series of revelations experienced by the hero concerning the nature of social injustice. His initial reaction to inequality is a textbook case of invidious social comparisons:

\footnotetext{
"At such hours the great, roaring, indifferent world of London seemed to him a huge organization for mocking at his poverty, at his inanition; and then its vulgarest ornaments, the window of third-rate jewelers, the young man in a white tie and crush-hat who dandled by, on his way to a dinner party... these familiar phenomena became symbolic, insolent, defiant, took upon themselves to make him smart with the sense that he was out of it." (page 164)
}

Resentment is soon followed by rage and frustration with the perceived indifference of the world toward the visible evidence of inequalities: 


\begin{abstract}
"And on top of it all, society lives! People go and come, and buy and sell, and drink, and drink and dance, and make money and make love, and seem to know nothing and suspect nothing and think of nothing; and iniquities flourish, and the misery of half of the world is prated about as a "necessary evil", and generations rot away and starve, in the midst of it, and day follows day, and everything is for the best in the best of possible worlds." (page 330)
\end{abstract}

What is to be done? In a moment of passion, Hyacinth resolves to take the dilemma into his own hands-he joins one of the underground terrorist networks, which were a notable feature of life in the 19th century. It is the hero's chilling response to social injustice that makes The Princess Casamassima as relevant today as when it was written. Yet Henry James is too subtle a novelist to simply let the hero follow through on his resolve. Almost from the moment that he pledges to give up his life for the terrorists' cause, Hyacinth is assailed by doubts, and begins to undergo a change of heart. Paradoxically, his deepening relationship with the Princess reveals to him both the splendour and the beauty of the world (at least as enjoyed by the lucky few). He tastes love, even though it remains unrequited and ultimately it destroys him. Gradually, it dawns on him that violence and destruction cannot pave the path to a lasting equality of the human condition. Yet too late to extricate himself from his underground connections, the hero's life ends in tragedy.

For the social epidemiologist, James' masterpiece abounds with insights concerning the nature of social inequalities, as well as the causes and consequences of individual actions to remedy them. Henry James, despite his own comfortable upbringing, fully grasped the causal link between deprivation and social ills. A succinct passage in the novel even summarises what social epidemiologists refer to nowadays as social causation (in contrast with social selection):

\begin{abstract}
"The low tone of our fellow-mortals is a result of bad conditions; it is the conditions I want to alter. When those that have no start to speak of have a good one, it is but fair to infer that they will go further." (page 444)
\end{abstract}

\section{THE RISE OF SILAS LAPHAM, BY WILLIAM DEAN HOWELLS $(1885)^{2}$}

William Dean Howells was a personal friend of Henry James, and a lifelong sympathiser of socialism. In 1887, he was the only prominent American writer to risk a public plea on behalf of the Chicago anarchists who had been wrongly convicted of the bombing that took place during the Haymarket Riots, in which labour unions agitated for a eight hour work day. Published just a year before The Princess Casamassima, the Rise of Silas Lapham is set in Boston during the waning years of its economic and political influence (as the power base of American society shifted toward New York). This was the Gilded Age-a satirical label invented by Mark Twain-during which American society witnessed an unprecedented concentration of wealth. It was also a ruthless age when the nation's mores fell in the grip of laissez faire capitalism and social Darwinism. As noted by Kevin Phillips in Wealth and Democracy: A Political History of the American Rich, ${ }^{3}$ the Gilded Age marked a turning point in American political philosophy when "the notion that government should not interfere on the side of the rich was reworked into the theorem that government had no business interfering on behalf of the downtrodden." (page 42-43)
Despite the long held notion that America was safe from the inequalities that prevailed in aristocratic Europe, historical records indicate that the concentration of wealth in the former had overtaken the latter by the late $1880 \mathrm{~s}^{3}$ In Massachusetts, where the top $8 \%$ owned $83 \%$ of the wealth in 1859-61 (just before the outbreak of the civil war), they had $90 \%$ by $1879-81 .{ }^{3}$ Unchecked capitalism threatened the foundations of social order. Even the comfortably well off were not immune to feeling the pressure of being overtaken by the nouveau riche. A character in Howells' novel, a scion of Old Bostonian society, laments:

"But the suddenly rich are on a level with any of us nowadays. Money buys positions at once... There's no doubt but money is to the fore now. It is the romance, the poetry of our age." (page 918)

The hero of Howells' novel, Silas Lapham, represents just such a specimen of the rising class of self made millionaires (he makes his fortune on a mineral paint mine he discovers on his father's Vermont farm). Much of the comedy and social commentary of Howells' novel derive from Lapham's awkward social encounters with Boston society through his daughters' entanglement with the heir of an old Boston family. However, the novelist is never condescending towards his hero-after all, Lapham embodies the vitality, the rugged individualism, and practical outlook of the American businessman. He openly boasts of not having the time of day to waste on reading frivolous novels; he only reads the newspapers, The Events, at that.

Unfortunately, economic fortune seems to beget the desire for even more accumulation. The hero begins to stray far from his economic base (the production of paint), and through a morally clouded partnership begins to dabble in speculative stocks. When his stocks tumble and he is forced into bankruptcy, Lapham is brought to the brink of temptation. He flirts with the idea of entering a shady business deal to get out of his financial difficulties. In the end, only his conscience, shored up by wife, saves him.

Lapham grapples at both a business and personal level with moral choices-whether it be in the paint or marriage market-and on balance makes the right choices, hence the "rise' of the novel's title, despite his personal financial collapse. Although he loses his fortune he regains a degree of stability and mental health.

\section{THE OCTOPUS, BY FRANK NORRIS $(1901)^{4}$}

In the final analysis, Howells' portrait of the American capitalist is benign, even tinged with a grudging admiration for his integrity and character. The same could not be said of Frank Norris, the young novelist mentored by Howells, whose portrayal of the rise of capitalism is decidedly darker, even sinister. In 1899, Norris conceived of a vast trilogy, The Epic of Wheat, which would follow the production of wheat in the fields of California, to its brokerage and price manipulation in the commodities market of Chicago, and finally its consumption in the famine stricken countries of Europe. The projected trilogy would expose the vast economic forces that were transforming American society, landscape, and psyche during that period. Norris got as far as completing the first two parts of his trilogy-The Octopus (1901) and The Pit (1903) - before he died at age 32 of a ruptured appendix.

The octopus of the title is a metaphor for the vast tentacles of the Southern Pacific Railroad (renamed as the Pacific and Southwestern Railroad in the novel) reaching out to all corners of the state of California, and on which the wheat growers of the San Joaquin Valley depended for the distribution of their harvest. The novel is a fictional re-telling of 
an actual dispute, which took place in 1880 between the wheat farmers and the railroad monopoly.

Railroads featured prominently in the "giantising" of fortunes during the Gilded Age, including those of John J Astor, Cornelius Vanderbilt, and Jay Gould. The influence and corruption of these "robber barons" have been amply recorded. In the words of Phillips, "railroads became the first corporate Goliaths, capturing legislatures and buying judges as lightly as they bridged rivers and bypassed uncollaborative towns and counties." Every conceivable trick is played by the railroad company on the farmers, ranging from arbitrary increases in the tariffs to transport crops, to the imposition of byzantine regulations designed to strip the wheat growers of the last ounce of their profits. The wheat growers attempt to retaliate by installing their own men on the California Railroad Commission through bribery and corruption. But their conspiracy to infiltrate the Commission is doomed from the start. The Southern Pacific Railroad ruled California, and the wheat farmers in Norris' novel know full well that they are powerless in resisting its monopoly:

"Shelgrim [the fictional owner of the Pacific and Southwestern Railroad] owns the courts... He's got the Railroad Commission in his pocket. He's got the Governor of the State in his pocket. He keeps a million-dollar lobby at Sacramento every minute of the time the legislature is in session; he's got his own men on the floor of the United States Senate. He has the whole thing organized like an army corps. What are you going to do? He sits in his office in San Francisco and pulls the strings and we've got to dance." (page 104-5)

In the words of the historian Arthur Schlesinger Jr (quoted in Phillips, ${ }^{3}$ page xvi), America had become by then, "in an ironical perversion of Lincoln's words at Gettysburg ... a government of the corporations, by the corporations and for the corporations."

The final, bloody confrontation between the railroad and farmers is brought about when the company demands an outrageous price for the land that it has been leasing to the farmers. Using dummy buyers, the company moves to evict the farmers from their homesteads. A shoot out with the US marshals hired by the company leaves most of the wheat farmers dead. Toward the end of The Octopus, one of the few survivors of the massacre travels to San Francisco to confront the Railroad's owner, but instead receives a stern lecture on the business ethics of the new age:

"Try to believe this - to begin with-that railroads build themselves. Where there is demand sooner or later there will be a supply... You are dealing with forces, young man, when you speak of Wheat and the Railroads, not with men. There is the Wheat, the supply. It must be carried to feed the People. There is the demand. The Wheat is one force, the Railroad, another, and there is the law that governs them-supply and demand." (page 576)

Gone are the moral scruples of an old fashioned businessman like Silas Lapham, which have been replaced with the dispassionate calculus of economic analysis. The refusal of the railroad magnate to acknowledge the human costs of his actions was mirrored in real life by the failure of professional economists to face up to the inequities of the age. As Robert Heilbroner describes in his fascinating history of economic thought (The Worldly Philosophers, 1953,5), the reaction of American economists to the realities of the Gilded Age amounted to "not very much":
"The fantastic game of monetary cutthroat was described as the process of "thrift and accumulation"; the outright fraud as "enterprise"; the gilded extravagances of the age as colorless "consumption". Indeed, the world was so scrubbed as to be unrecognizable. One might read such leading texts as John Bates Clark's Distribution of Wealth and never know that America was a land of millionaires; one might peruse F.H. Taussig's Economics and never come across a rigged stock market." (page 165)

Generations of critics have complained about the problematic denouement of The Octopus, which need not detain us here-readers should judge for themselves. But whatever its faults (and there are many in this sprawling 650 page book), there is no gainsaying the propulsive force of Norris' narrative. In its most hard hitting passages, Norris' fiction matches, if not surpasses, the raw power of the investigative, "muck raking" journalism of the period, whose reporting of political corruption and social injustice spurred the reforms of the early 20th century Progressive Era.

\section{SISTER CARRIE, BY THEODORE DREISER (1900) ${ }^{6}$}

The young Theodore Dreiser was discovered by Frank Norris while Norris worked as a part time manuscript reader at the publishing company of Doubleday, Page and Co. Norris vigorously championed the publication of Sister Carrie. The novel (and the heroine's career) is launched as Carrie Meeber, an 18 year old country girl from Wisconsin, boards the train bound for Chicago carrying her entire worldly belongings, consisting of "a small trunk, a cheap imitation alligator-skin satchel, a small lunch in a paper box, and a yellow leather snap purse, containing her ticket, a scrap of paper with her sister's address in Van Buren Street, and four dollars in money." (page 1)

Propelled only by her insistent yearnings for a better life, the unsophisticated Carrie claws her way out of poverty, first in Chicago, and later in New York City. Her upward mobility is exactly mirrored by the gruesome downward drift of the middle class resort manager, Hurstwood, who falls hopelessly in love with her, to the point of abandoning his marriage and eloping with her to New York with embezzled money. Money-both its presence and absence-assumes an almost fetishistic quality in Dreiser's book, in which the novelist lays bare the heroine's weekly income and expenditures with near documentary zeal. At first, Dreiser seems merciless in his condemnation of Carrie's shallow preoccupation with having money. However, she is not an unsympathetic character; she is simply one of the millions of faceless souls striving to rise above the margins of poverty and live the American Dream.

Dreiser's bitterest invective is instead levelled at the grim conditions of those at the bottom of the social heap; those who have fallen through the threadbare safety net of American society. This group is exemplified by the character of Hurstwood, a once successful middle class manager, who throws away his job, marriage, and reputation for his folie d'amour. A fugitive from justice, he tries his hand at a succession of jobs, starting as a tavern owner, then a hotel labourer, and eventually ending up as a "scab" tram driver during the violent 1895 Brooklyn street car strike (in which the drivers were demanding $\$ 2.25$ for a 10 hour work day). Failing in all of these, and abandoned by Carrie, he is ultimately reduced to homelessness, begging in the streets, and standing in breadlines. Despite over a century of economic development, Dreiser's depiction of the economic contrasts in Manhattan (or for that matter, of any major American city) remains as accurate today as it was in the 1890s: 


\begin{abstract}
"Along Broadway men picked their way in ulsters and umbrellas. Along the Bowery, men slouched through it with collars and hats pulled over their ears. In the former thoroughfare business men and travelers were making for comfortable hotels. In the latter, crowds in cold errands shifted past dingy stores." (page 363)
\end{abstract}

Hurstwood's ghastly coup de grace comes when contemplating suicide, he realises he cannot afford it:

\begin{abstract}
"'"'That's right," he said; "I'm no good now. I was all right. I had money. I'm going to quit this," and, with death in his heart, he started down toward the Bowery. People had turned on the gas before and died; why shouldn't he? He remembered a lodging-house where there were little, close rooms, with gas-jets in them, almost pre-arranged, he thought, for what he wanted to do, which rented for fifteen cents. Then he remembered that he had no fifteen cents." (page 361)
\end{abstract}

By this time, he has been long forgotten by his former lover, who has gone on to hit the mother lode of American Dreams. For the world has discovered Carrie's dubious "talent" for acting. After her debut in a tawdry fundraising performance for the local Elks Lodge, Carrie goes on to work as a chorus girl in a Broadway revue. The novel closes with the heroine, alone in her splendid new penthouse rooms, dreaming of still greater successes and conquests to come: "Though often disillusioned, she was still waiting for that halcyon day when she should be led forth among dreams become real." (page 369) Upward mobility seems certainly preferable to downward mobility for health.

THE HOUSE OF MIRTH, BY EDITH WHARTON (1905) ${ }^{7}$ Throughout her early career, Edith Wharton suffered from an unflattering critical comparison with Henry James. However, the publication of The House of Mirth, when she was aged 42, dispelled any such doubts and firmly established her as an independent voice in the American canon. The book has often been hailed as the quintessential novel of the Gilded Age; even Henry James seems to have admired it. Like Sister Carrie, The House of Mirth examines the precarious position of women in American society at the turn of the century and the rigid rules governing their behaviour and relative social position in the hierarchy.

The sympathetic heroine of the novel, Lily Bart, is an 11 year veteran of the Fifth Avenue social set. Reduced to living with her frugal aunt after the financial ruin of her father and the consequent premature death of her mother, Lily (who is already 29 years old) is desperate to improve her fortunes through a good marriage and avoid "the squalid compromises of poverty." Her inability to settle on a mate is aggravated by her awareness of the lasting consequences of marrying for money:

\begin{abstract}
"[Lily] had been bored all afternoon by Percy Gryce [one of the wealthy suitors who materializes early in the novel] - the mere thought seemed to waken an echo of his droning voice-but she could not ignore him on the morrow, she must follow up her success, must submit to more boredom, must be ready with fresh compliances and adaptabilities, and all on the bare chance that he might ultimately decide to do her the honour of boring her for life" (page 23).
\end{abstract}

The psychological contest throughout The House of Mirth thus takes place between Lily's pressing need for money on the one hand ("one of the conditions of citizenship is not to think too much about money, and the only way not to think about money is to have a great deal of it," page 56), and on the other hand, her dread of becoming trapped in the dull, meaningless routines of the married women in her circlethere apparently being no felicitous middle ground in New York high society. As remarked by the critic Elizabeth Ammons, ${ }^{8}$ Edith Wharton along with Thorstein Veblen, ${ }^{9}$ was one of the earliest social critics to dissect the institution of marriage in upper class American society:

\begin{abstract}
"According to Veblen, the leisure-class wife has a definite job to perform, and "it is an occupation of an ostensibly laborious kind. It takes the form, in large measure, of painstaking attention to the service of the master," which means deferring, like the rest of his servants, to his wishes and wearing his livery. Like his footman, the gentleman's wife wears clothing that shows she does not need to engage in sweated labor. Indeed, her huge hats, high heels, voluminous skirts, exceedingly long hair, and corseted midriff all render her unfit for exertion and label her some man's costly possession. She is human chattel with an ornamental function, the prized domestic trophy whose leisure, dependence, and expenditure evidence her husband's financial prowess. For Veblen, and for Wharton, the lady of the leisure class is not an individual to be envied. She is a symbol to be studied, a totem of patriarchal power." (page 348)
\end{abstract}

Anyone familiar with the late 20th century novels of Tom Wolfe (for instance, The Bonfire of the Vanities ${ }^{10}$ ) will be reminded of parallels to his satirical descriptions of Wall Street "trophy wives" and "elbow candy".

Ultimately, Lily rebels against the injustice of limited opportunities available to women of her station. But her one act of personal rebellion-of procrastinating in her choice of a suitor-leads to predictable disaster. One by one, she squanders her opportunities to make a profitable match. The women of her social circle, jealous of Lily's beauty and ability to attract men, start to turn against her. A whispering campaign leads to the gradual ruin of her reputation. By turns, Lily is cast out of New York society, ostracised by her former companions, disinherited by her prudish aunt, and reduced to taking up residence in a shabby boarding house. Like the Princess Casamassima, Lily Bart at the beginning of the novel professes a charitable interest in the plight of the poor. But whereas the working conditions of the poor remain only a subject of theoretical interest to the Princess, for Lily they become a grim reality when she is forced to work in a milliner's shop to pay her mounting bills. And unlike Carrie Meeber, Lily Bart soon discovers to her humiliation that her upbringing has not equipped her with the necessary skills for survival:

\section{"It was bitter to acknowledge her inferiority even to herself, but the fact had been brought home to her that as a bread-winner she could never compete with professional ability. Since she had been brought up to be ornamental, she could hardly blame herself for failing to serve any practical purpose." (page 232)}

Depressed and sick from nervous exhaustion, Lily ends her life with an overdose of chloral sleeping potion.

\section{CONCLUDING COMMENTS}

Financial ruination, three suicides, and half a dozen dead bodies strewn across a wheat field-such is the human toll 
extracted by the relentless march of capitalism in the pages of these novels. Whereas the characters are fictional, the descriptions of their social milieu, as well as the background of historical events through which they live, remain disturbingly real.

Revealingly there are few indications of any social movements in these novels, such as unions, which could have provided the countervailing power to promote social change and improved general welfare. Against a background of unbridled consumption by the rich, and in the absence of even a minimal safety net, destitute widows such as Hilda Hooven in The Octopus literally die of starvation in the street, while young women, such as Minna her daughter, are forced into prostitution. Through lack of labour market regulation, longstanding employees, such as Dyke (also in The Octopus) are sacked without any financial compensation and fall into depression and crime. The wave of reactive social reforms that had swept across Europe in the wake of the thwarted revolutions made only small and slow inroads into America, the land of individual opportunity and "sharp incentives", where people were expected to "pull themselves up by their own boot straps." The Governor of California in The Octopus tells the ranchers:

"If I were to name the one crying evil of American life... it would be the indifference of the better people to public affairs... Every State has its own grievance. If it is not a railroad trust it is a sugar trust, or an oil trust, or an industrial trust that exploits the People, because the People allow it. The indifference of the People is the opportunity of the despot." (page 304)

These novels are all written in the third person by novelists who were primarily observers of the nuances of social position rather than radical activists or reformers. Like many literary intellectuals they create sympathetic individual characters from all classes in the social hierarchy, but they also embody the political elite's antipathy towards egalitarian collective solutions by despising the poor en masse as nasty and brutish, a viewpoint John Carey perceptively explores in The Intellectuals and the Masses. ${ }^{11}$

A gentleman squire in The Rise of Silas Lapham, with a hint of a radical past fighting with Garibaldi in Italy, points out the unfairness of the rich owning several houses, which are often empty in summer, while the poor swelter and become ill in miserable overcrowded conditions. He proposes an early version of squatting, until his wife reminds him how poorly behaved the poor are, whereupon he immediately drops his fancy.

Presley the poet/observer in The Octopus initially has no natural affinity with the Californian people he has chosen to live among:

"These uncouth brutes of farmhands and petty ranchers, grimed with the soil they worked upon, were odious to him beyond words. Never could he feel any sympathy for them, nor with their lives, their ways, their marriages, deaths, bickerings, and all the monstrous round of their sordid existence." (page 3)

None the less a cynical comment by one of the poet's friends presents a resonant challenge to those modern social epidemiologists preoccupied with describing social inequalities, as compared with intervening in the real world to reduce them:

"The social reformer writes a book on the inequity of the possession of land, and out of the proceeds buys a corner lot. The economist who laments the hardships of the poor allows himself to grow rich upon the sale of his book" (page 331-2)

The complete absence of any black characters in these novels is a telling reminder of social exclusion that half a century later Ralph Ellison would describe in the Invisible Man $(1952)^{12}$ or in William Du Bois's telling phrase of the necessity for black people, even in the South, to live "beyond the veil". ${ }^{13}$

Needless to add, many other works belong to the social epidemiologist's lifetime reading list, from earlier periods (for example, the Industrial Revolution in Britain and Western Europe), as well as later periods (the Second Gilded Age and the Great Depression in America)—but that is another story.

\section{ACKNOWLEDGEMENTS}

IK wishes to acknowledge the "Club Anakena", and the memorable dinner with Ildefonso Hernandez and Paco Bolumar, which inspired this article.

\section{Authors' affiliations}

I Kawachi, Department of Society, Human Development and Health, Harvard School of Public Health, Boston, USA

P Howden Chapman, Department of Public Health, Wellington School of Medicine and Health Sciences, University of Otago, New Zealand

Funding: none.

Conflicts of interest: none declared.

\section{REFERENCES}

1 James H. The Princess Casamassima (1886). London: Penguin Books, 1987.

2 Howells WD. The rise of Silas Lapham (1885). In: Novels 1875-1886. New York: The Library of America, 1982.

3 Phillips K. Wealth and democracy. A political history of the American rich. New York: Broadway Books, 2002.

4 Norris F. The Octopus (1901). London: Penguin Books, 1986.

5 Heilbroner R. The worldly philosophers. (1953). London: Penguin Books, 1980.

6 Dreiser T. Sister Carrie. (1900). New York: W W Norton, 1970.

7 Wharton, Edith. The house of mirth. (1905). New York: W W Norton, 1990

8 Ammons E. Edith Wharton's hard-working Lily: The house of mirth and the marriage market. (1980) Reprinted in: The house of mirth. New York: W W Norton, 1990:345-57.

9 Veblen T. The theory of the leisure class. (1899) London: Penguin Books, 1979.

10 Wolfe T. The bonfire of the vanities. New York: Bantam Books, 1987.

11 Carey J. The intellectuals and the masses: pride and prejudice among the literary intelligentsia, 1880-1939. London: Faber and Faber, 1992.

12 Ellison R. Invisible man. (1952). New York: Penguin Books, 1984.

13 Du Bois WEB. The souls of black folks. (1903). New York: Barnes and Noble Classics, 2003. 